AgNIESZKA LUKów

Uniwersytet Pedagogiczny, Kraków, Polska

\title{
Procesy suburbanizacyjne aglomeracji rzeszowskiej i Rzeszowskiego Obszaru Metropolitalnego w warunkach kryzysu
}

\author{
Processes of suburbanization in the agglomeration \\ of Rzeszow and Rzeszow Metropolitan Area \\ during the crisis
}

\begin{abstract}
Streszczenie: Kryzys gospodarczy implikuje wiele procesów zachodzących w gospodarce poprzez spowolnienie rozwoju gospodarczego, społecznego i kulturowego oraz ograniczenie postaw przedsiębiorczych. Efektem kryzysu jest także wplyw na szybki spadek aktywności ekonomicznej, przejawiającej się w zakłóceniu płynności finansowej, zmniejszeniu produkcji, ograniczeniu zatrudnienia oraz działalności inwestycyjnej, zmniejszeniu zasobów finansowych przedsiębiorstw i ludności. Sytuacja kryzysowa wpływa na zmiany tempa rozwoju struktur regionalnych i krajowych. Na tym tle w niniejszych rozważaniach podjęto próbę wskazania wybranych problemów społeczno-ekonomicznych i skutków funkcjonowania miasta Rzeszowa i jego otoczenia w obliczu kryzysu. Celem pracy jest ukazanie zmian społeczno-demograficznych i gospodarczych wplywających na procesy suburbanizacyjne aglomeracji rzeszowskiej oraz Rzeszowskiego Obszaru Metropolitalnego (ROM). Zakres czasowy opracowania obejmuje głównie lata 1995-2012, a więc m.in. okres kryzysu ekonomicznego ostatnich lat. Przedmiotem analizy jest zarówno problematyka demograficzna (dynamika zaludnienia, ruch naturalny, saldo migracji) jak i wplyw kryzysu na suburbanizację aglomeracji rzeszowskiej.
\end{abstract}

Abstract: The economic crisis implies a lot of the processes taking place in the economy by slowing economic, social, cultural and limits entrepreneurial attitudes. The crisis also has an impact on the rapid decline in the economic activity, manifests in disruption in financial fluidity, the reduction of production, employment and investment activities, tas well as the financial resources of companies and people. The crisis affects the change in the rate of development of regional and national structures. The author tries to indicate the selected socio-economic problems and the effects of the functioning of Rzeszow city and its surroundings in the face of crisis. The aim is to show in the socio - economic and demographic the changes affecting the suburbanization processes in the agglomeration of Rzeszow and Rzeszow Metropolitan Area. The time horizon of the study includes the period of 1995-2012 the period of the economic crisis of recent years. The subject of the analysis is the issue of population 
growth (population dynamics, natural motion, net migration) and the impact of the crisis on the suburbanisation of the agglomeration of Rzeszow

Slowa kluczowe: aglomeracja rzeszowska; kryzys; Rzeszowski Obszar Metropolitalny (ROM); Rzeszów; suburbanizacja

Keywords: agglomeration of Rzeszow, crisis; Rzeszow Metropolitan Area; Rzeszow, suburbanization

Globalny kryzys gospodarczy, którego pierwsze przejawy byly obserwowane w 2007 r., oceniany jest jako najgłębsza recesja gospodarki światowej od czasu Wielkiego Kryzysu z przelomu lat dwudziestych i trzydziestych XX w. (Rachwal, 2011).

Zauważalne w ostatnich latach znaczne osłabienie procesów rozwoju gospodarczego, społecznego i kulturowego to wlaśnie negatywne skutki kryzysu. Światowa sytuacja kryzysowa wplynęla m.in. na zmiany tempa rozwoju struktur regionalnych i krajowych. Kryzys wpływa na szybki spadek aktywności ekonomicznej, przejawiającej się w zakłóceniu płynności finansowej i prowadzi do zmniejszania produkcji, ograniczenia zatrudnienia oraz dzialalności inwestycyjnej, zmniejszenia zasobów finansowych przedsiębiorstw i ludności. a w konsekwencji do obniżenia poziomu oraz pogarszania się warunków życia (Zioło, 2011). Konsekwencją kryzysu są niższe dochody, zagrożenie bezrobociem, ograniczenia w udzielaniu przez banki kredytów - zwlaszcza hipotecznych. Spowolnienie gospodarcze i jego skutki obserwowane są we wszystkich dziedzinach życia i oddziałują także na ksztaltowanie się różnej skali ukladów przestrzennych. w tym na procesy suburbanizacyjne (Adamczyk, 2012).

W świetle powyższych przeslanek podjęto próbę wskazania wybranych problemów społeczno-ekonomicznych i skutków funkcjonowania miasta Rzeszowa i jego otoczenia - aglomeracji rzeszowskiej i Rzeszowskiego Obszaru Metropolitalnego (ROM) w obliczu kryzysu. Celem pracy jest ukazanie zmian spoleczno-demograficznych i gospodarczych wpływających na procesy suburbanizacyjne aglomeracji rzeszowskiej i ROM. Opracowanie dotyczy lat 1995-2012 (w niektórych przypadkach jest to krótszy przedzial czasowy), a więc m.in. okres kryzysu ekonomicznego ostatnich lat.

Na wstępie przedstawiono rozwój przestrzenny miasta Rzeszowa w ostatnich latach oraz delimitację aglomeracji rzeszowskiej i ROM. Następnie na podstawie danych statystycznych pozyskanych z Banku Danych Lokalnych Glównego Urzędu Statystycznego przedstawiono zmianę liczby ludności badanego obszaru oraz dokonano analizy zmian wskaźników przyrostu naturalnego, salda migracji i stopy bezrobocia. Na zakończenie omówiono zmiany nakładów inwestycyjnych $w$ przedsiębiorstwach, a także zmiany liczby mieszkań oddanych do użytkowania oraz pozwoleń wydanych na budowę budynków mieszkalnych.

\section{Suburbanizacja A METROPOLIZACJA}

Do najbardziej charaktery stycznych zjawisk w rozwoju współczesnych ośrodków miejskich należy proces suburbanizacji i związane z nim rozprzestrzenianie się miast. Jest to 
efekt kilku czynników, takich jak m.in. wzrost realnych dochodów ludności, mniejsze koszty dojazdów do pracy, czy pogarszające się warunki życia w centrach miast. Po zmianie ustroju politycznego oraz wprowadzeniu gospodarki rynkowej zaistniały warunki do szybkiego rozwoju budownictwa indywidualnego. Efektem jest intensywny rozwój zabudowy jednorodzinnej w strefach bezpośrednio otaczających miasta - proces ten jest zauważalny nie tylko w największych aglomeracjach, ale również w otoczeniu miast średniej wielkości (Słodczyk, 2011). Badania obejmujące obszar Polski wschodniej (Śleszyński, Czapiewski, 2011) wskazują nawet na istnienie procesu suburbanizacji rezydencjalnej dla mniejszych miast powiatowych, np. Sanoka, Jasła i Dębicy.

Pojęcie suburbanizacji jest wieloznaczne. Tradycyjnie jest to proces przenoszenia form przestrzennych miasta oraz form życia miejskiego poza miasto centralne, na tereny je otaczające, a także proces zespalania funkcjonalnego obszarów podlegających suburbanizacji z miastem centralnym. Proces ten uwidacznia się w przemieszczaniu się ludności i podmiotów gospodarczych z miasta centralnego do strefy podmiejskiej.

W literaturze przedmiotu suburbanizacja przedstawiana jest w trzech kontekstach przestrzennych:

- wewnątrz granic administracyjnych miasta centralnego (suburbanizacja wewnętrzna na wolnych do zainwestowania terenach miasta centralnego);

- poza granicami miasta centralnego w obrębie strefy podmiejskiej bliższej, która cechuje się względną ciąglością przestrzenną zainwestowania;

- poza strefą podmiejską bliższą - w obrębie strefy podmiejskiej dalszej, krajobrazowo przypominającej wieś, gdzie przeważają ekstensywne formy użytkowania ziemi (Lisowski, Grochowski, 2009).

Współczesna suburbanizacja to składowa szerszego procesu miejskich przeksztalceń, a mianowicie procesu metropolizacji. Jest to proces przeksztalcania zarówno powiązań funkcjonalnych obszaru metropolitalnego oraz jego przestrzeni miejskiej (Lisowski, Grochowski, 2009; Makieła, Fedan, 2007).

Metropolizacja przestrzeni to proces przekształcania się przestrzeni miejskich, związany ze zmianą relacji między miastem centralnym a jego zapleczem. Polega na osłabieniu lub zerwaniu związków gospodarczych miasta z otaczającym regionem i zastapieniu ich więziami z innymi metropoliami w skali kontynentalnej lub światowej. Rola regionu ogranicza się do pełnienia funkcji mieszkaniowych i rekreacyjnych dla mieszkańców metropolii, zaś nieciągłość przestrzeni oznacza, że „sąsiadem" w sensie gospodarczym i społecznym nie jest już otaczający region, lecz położona - często w dużej odległości - inna metropolia (Jałowiecki. 1999; Markowski, Marszał. 2006; Makieła. Fedan. 2007).

Metropolizacja przestrzeni jest procesem. który wiąże się z powstawaniem nowego jakościowo typu struktury przestrzennej. Proces ten przejawia się w ogniskowaniu rozwoju w wybranych fragmentach przestrzeni (regionach lub miastach), które odznaczają się przewagą nad innymi jednostkami. Metropolie skupiają światowy potencjal gospodarczy, naukowy, finansowy i kulturalny. Charakteryzują się dużą innowacyjnością i wysokim poziomem usług oraz przejmowaniem nadrzędnych funkcji w zarządzaniu gospodarką w skali ponadnarodowej (Kudełko, 2007; Markowski. Marszal. 2006). Metropolizację należy rozumieć 
jako uniezależnianie się metropolii od ich regionalnego zaplecza na rzecz kontaktów z pozostałą częścią świata (Gorzelak, Smętkowski. Jałowiecki. 2009). Dlatego też o tym. czy dane miasto zaliczamy do metropolii. decyduje nie jego wielkość, ale funkcje. które spełnia w przestrzeni krajowej i międzynarodowej. Mianem metropolii określa się coraz częściej miasta o mniejszej liczbie ludności, ale pełniące funkcje ponadregionalne i odznaczające się dużą dynamiką rozwojową. Metropolia rozwija wokół siebie strefę i tworzy wraz z nią obszar metropolitalny (Kudełko, 2007). Należy jednak zaznaczyć, jak wskazuje Śleszyński (2006), że pomimo licznych prac naukowych podejmujących tematykę metropolizacji polskiej przestrzeni, brak jest jednoznacznych wyników potwierdzających lub odrzucających tezę o metropolizacji zarówno poszczególnych przypadków, jak i całego zbioru aglomeracji, szczególnie na tle zachodzących procesów urbanizacji. Z punktu widzenia rozwoju gospodarczych funkcji kontrolnych polskich miast i ich powiazań z innymi metropoliami światowymi, można uznać, że proces metropolizacji zachodzi (Śleszyński, 2007). Biorąc natomiast pod uwagę powiązania $\mathrm{z}$ otaczającym regionem, to wiele badań wskazuje na to, że są one coraz silniejsze (Śleszyński, 2012), co przeczy teorii zrywania związków gospodarczych miasta z otaczającym regionem.

\section{DELIMITACJA OBSZARU BADAWCZEGO}

Rzeszów jest największym miastem południowo-wschodniej Polski i stolicą woj. podkarpackiego. Stanowi centralne miasto aglomeracji rzeszowskiej, jest także czlonkiem Unii Metropolii Polskich. Pelni funkcję glównego ośrodka administracyjnego, przemyslowego, handlowo-usługowego, akademickiego i kulturalnego w tej części kraju (Kudelko, 2007).

W celu utrzymania dynamicznego rozwoju Rzeszowa wladze rozpoczęly starania o pozyskanie nowych terenów pod inwestycje, w konsekwencji czego od $2006 \mathrm{r}$. Rzeszów powiększal się o przyległe sołectwa (ryc. 1): Slocinę (2006 r. $\left.-9,16 \mathrm{~km}^{2}\right)$, Załęże $\left(2006 \mathrm{r} .-5,20 \mathrm{~km}^{2}\right)$, Przyby szówkę (2007 r. i 2008 r. - 16.26 km²), Zwięczycę (2008 r. - 7.23 km²), Bialą (2009 r. $-6,06 \mathrm{~km}^{2}$ ), Budziwój (2010 r. - 17,50 km²), część Milocina (2010 r. - 1,27 km²) (http://www. rzeszow.pl/miasto-rzeszow/rozszerzenie-granic-miasta/jak-roslo-nasze-miasto).

W latach 2006-2010 terytorium Rzeszowa zostało powiększone lącznie o $62,68 \mathrm{~km}^{2}$ z 53,69 do 116,37 km² (czyli o 116,7\%). a liczba ludności wzrosła o 20,7 tys. osób (z 158,5 tys. do 179,2 tys., czyli o 13\%). Sytuacja ta utrudnia proces analizy danych demograficznych i spoleczno-ekonomicznych, gdyż nie jest możliwe ich analizowanie w badanym okresie na jednolitym obszarze.

Aglomeracja rzeszowska jest aglomeracją monocentryczną. Delimitacja przyjęta w Planie Zagospodarowania Przestrzennego Województwa Podkarpackiego (2002) określa, że w skład aglomeracji rzeszowskiej wchodzą miasta: Rzeszów, Łańcut, Glogów Małopolski, Tyczyn, Boguchwala ${ }^{1}$ oraz gminy: Bialobrzegi, Boguchwala. Czarna, Głogów Małopolski, Krasne, Łańcut, Świlcza, Trzebownisko, Tyczyn. Zasięg aglomeracji rzeszowskiej przedstawiony został na ryc. 2 .

\footnotetext{
Prawa miejskie od 1 stycznia 2008 r.
} 


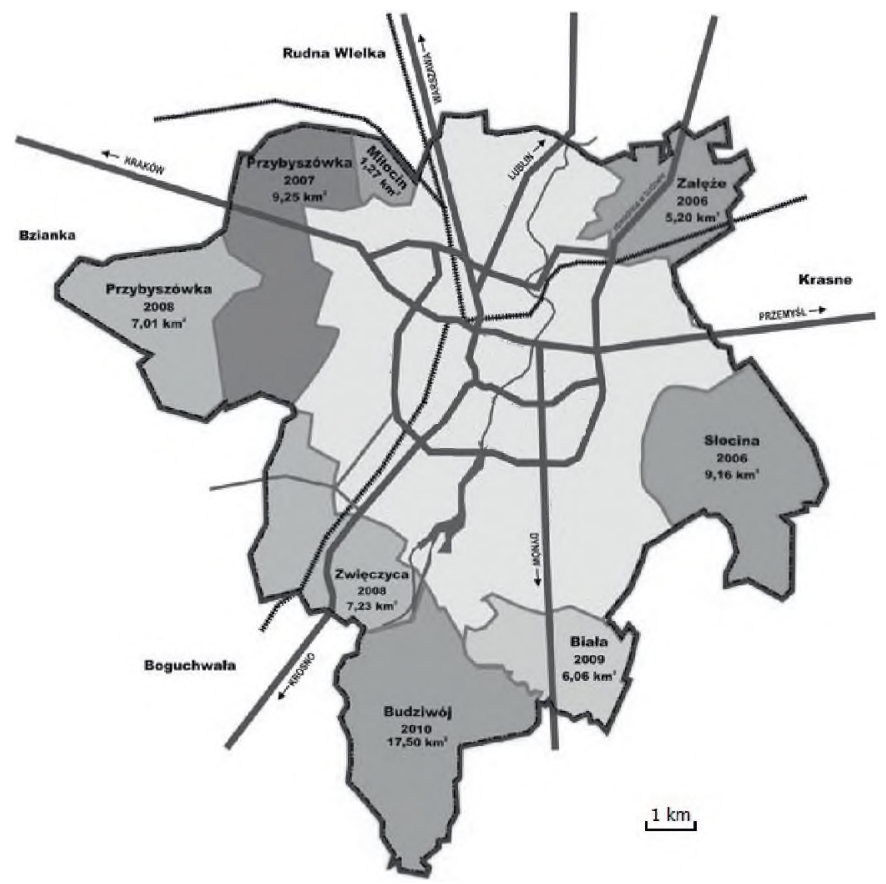

Ryc. 1. Rozszerzanie granic miasta Rzeszowa od $2006 \mathrm{r}$.

Źródło: http://www.rzeszow.pl/miasto-rzeszow/rozszerzenie-granic-miasta/jak-roslo-nasze-miasto

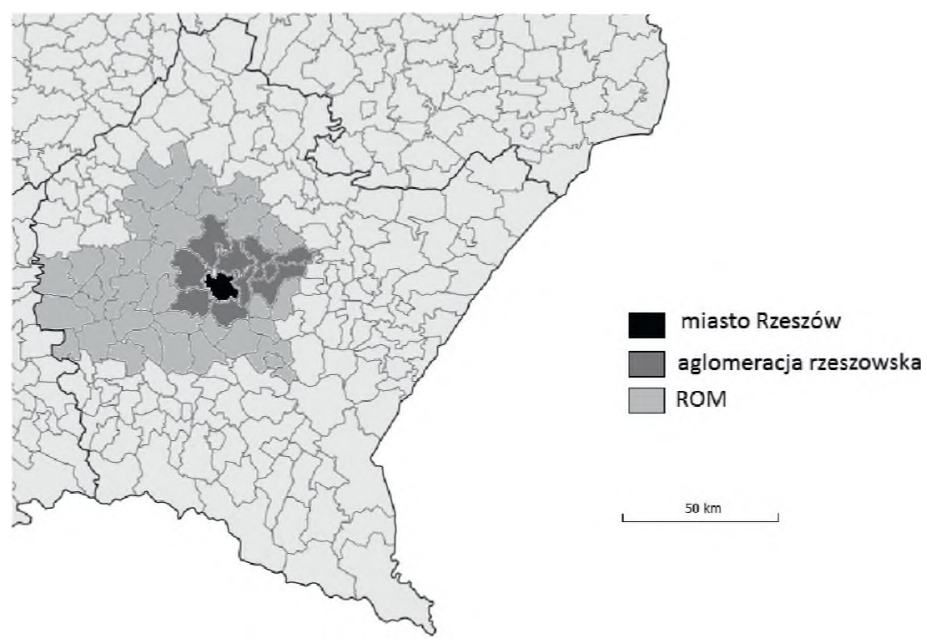

Ryc. 2. Zasięg aglomeracji rzeszowskiej oraz ROM Źródło: opracowanie własne 
Literatura dostarcza różnych delimitacji obszaru metropolitalnego Rzeszowa. P. Śleszyński (2013) zalicza do Miejskiego Obszaru Funkcjonalnego Rzeszowa 14 gmin: Rzeszów - rdzeń. Błażowa (miejsko-wiejska). Boguchwała (miejsko-wiejska), Chmielnik (wiejska), Czarna (wiejska), Czudec (wiejska). Glogów Małopolskie (miejsko-wiejska), Krasne (wiejska), Lubenia (wiejska), Łańcut (miasto), Łańcut (wiejska). Świlcza (wiejska), Trzebownisko (wiejska), Tyczyn (miejsko-wiejska).

Z kolei A. Winiarczyk-RaźniakiP. Raźniak (2012) przyjmujądelimitację Rzeszowskiego Obszaru Metropolitalnego za Unią Metropolii Polskich. Według tej delimitacji ROM obejmuje 6 powiatów: Miasto Rzeszów, powiat rzeszowski. powiat łańcucki. powiat ropczyckosędziszowski, powiat kolbuszowski, powiat strzyżowski.

Jak przyjmuje J. Kudełko (2007), ROM obejmuje 7 powiatów: miasto Rzeszów. będące ośrodkiem centralnym, oraz 6 powiatów województwa podkarpackiego: rzeszowski, ropczycko-sędziszowski, kolbuszowski, łańcucki, strzyżowski i dębicki. W niniejszym artykule przyjęto delimitację ROM za J. Kudelko, gdyż delimitacja ta obejmuje największy obszar. co pozwoli uzyskać szerszy obraz zachodzących procesów. Marszałek Województwa Podkarpackiego, Prezydent Miasta Rzeszowa oraz Starostowie ww. powiatów podpisali 4 maja 2005 r.. porozumienie partnerskie w sprawie Rzeszowskiego Obszaru Metropolitalnego. Zasięg ROM przedstawiony został na ryc. 2.

ROM znajduje się w początkowej fazie rozwoju i należy go traktować jako potencjalny obszar rozwoju funkcji metropolitalnych, który przy odpowiednio prowadzonej polityce rozwoju może w przyszłości pełnić funkcje metropolitalne o znaczeniu ponadregionalnym (Kudełko, 2007).

\section{ZMIANY SPOEECZNO-DEMOGRAFICZNE I GOSPODARCZE}

W tabeli 1 ukazane zostaly zmiany liczby ludności Rzeszowa, aglomeracji rzeszowskiej oraz ROM obejmujące rok 1988 oraz w latach 1995-2012. Z przedstawionych danych wynika, że badany okres charakteryzuje się systematycznym wzrostem liczby ludności zarówno w aglomeracji (z 294285 mieszkańców w 1988 r. do 337470 w 2012 r.), jak i w ROM (z 689528 mieszkańców w 1988 r. do 760068 w 2012 r.).

W badanym przedziale czasowym występuje dodatni przyrost naturalny (ryc. 4). Dane pokazują, że tendencja spadkowa utrzymywała się do okresu 2002-2003, a następnie nastąpil wzrost, aż do 2009 r., kiedy dało się zauważyć znaczne jego obniżenie na obszarze Rzeszowa i aglomeracji. Na początku badanego okresu najwyższymi wartościami przyrostu naturalnego charakteryzowal się obszar ROM (3,65\%), niższe wartości notowano na obszarze aglomeracji $(2.82 \%$ ), a najniższy przyrost naturalny występował na obszarze miasta (1,83\%o). Tendencja ta ulegla odwróceniu w latach 2005-2006 - od tej pory najwyższe wartości przyrostu naturalnego notowane są na obszarze Rzeszowa $(3,71 \%$ ), nieco niższe charakteryzują aglomerację $(2,86 \%)$, a najniższe - ROM $(2,47 \%)$. 
Tab. 1. Liczba ludności Rzeszowa, aglomeracji rzeszowskiej oraz ROM w roku 1988 oraz w latach $1995-2012$

\begin{tabular}{|c|c|c|c|}
\hline Lata & Rzeszów & Aglomeracja rzeszowska & ROM \\
\hline 1988 & 148560 & 294285 & 689528 \\
\hline 1995 & 160271 & 312793 & 723084 \\
\hline 1996 & 160837 & 314452 & 725955 \\
\hline 1997 & 161267 & 315937 & 728656 \\
\hline 1998 & 162049 & 317673 & 731833 \\
\hline 1999 & 160601 & 317314 & 728276 \\
\hline 2000 & 160779 & 318580 & 730407 \\
\hline 2001 & 160431 & 319474 & 732258 \\
\hline 2002 & 159791 & 319811 & 733341 \\
\hline 2003 & 159088 & 320504 & 734358 \\
\hline 2004 & 159020 & 321715 & 735839 \\
\hline 2005 & 158539 & 322508 & 737223 \\
\hline 2006 & 163508 & 324062 & 738392 \\
\hline 2007 & 166454 & 325164 & 739772 \\
\hline 2008 & 170653 & 327048 & 742299 \\
\hline 2009 & 172770 & 328217 & 744467 \\
\hline 2010 & 179199 & 332364 & 754420 \\
\hline 2011 & 180031 & 334495 & 756933 \\
\hline 2012 & 182028 & 337470 & 760068 \\
\hline
\end{tabular}

Źródło: opracowanie własne na podstawie danych GUS

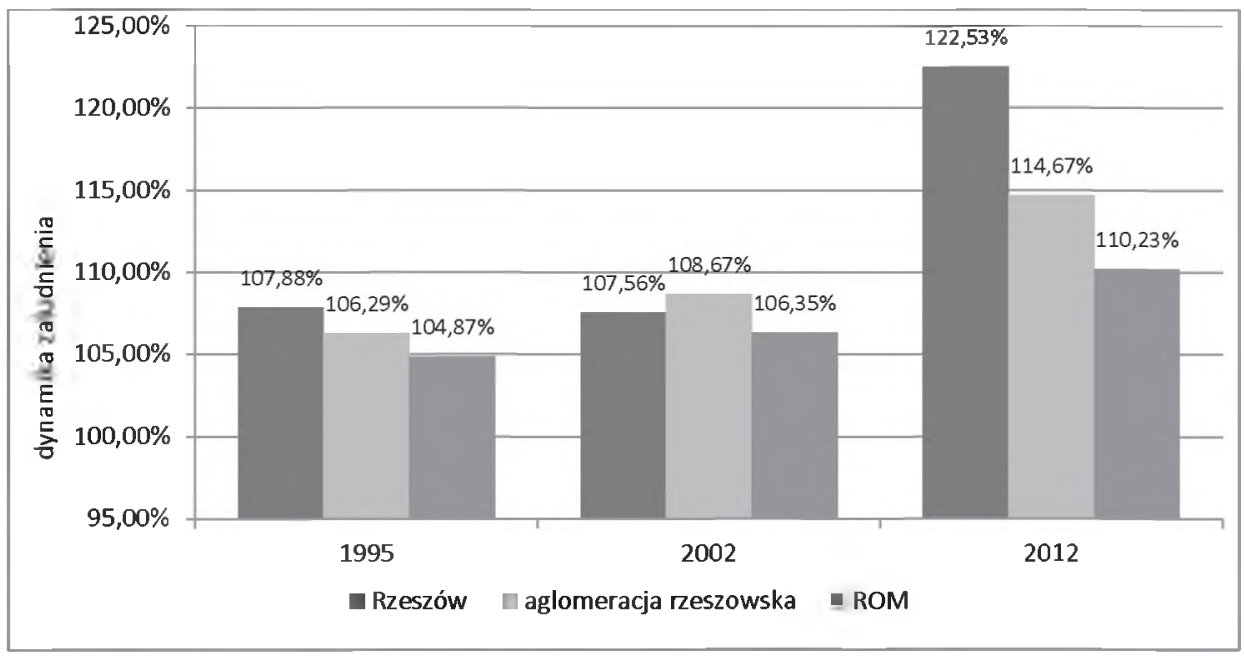

Ryc. 3. Dynamika zaludnienia Rzeszowa, aglomeracji rzeszowskiej i ROM (1988 r. = 100\%)

Źródło: opracowanie własne na podstawie danych GUS 


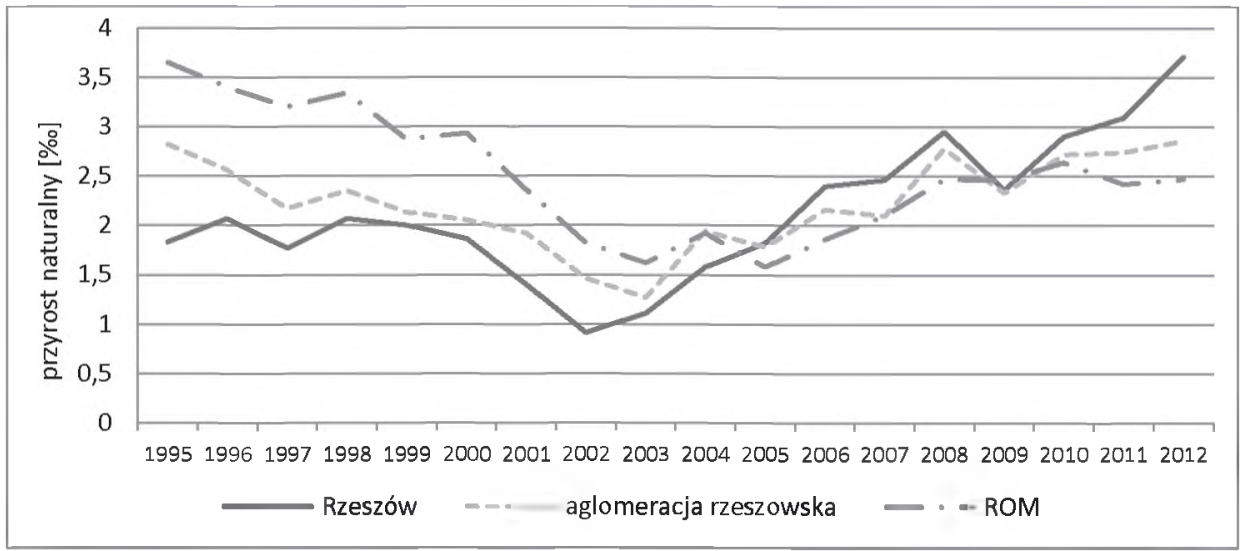

Ryc. 4. Zmiany przyrostu naturalnego na obszarze Rzeszowa, aglomeracji rzeszowskiej i ROM w latach 1995-2012

Źródło: opracowanie własne na podstawie danych GUS

Zmiany te mogą być konsekwencją wlączenia w obszar miasta przyległych gmin, które dotychczas należaly do przedmieść, gdzie osiedlała się głównie ludność w wieku rozrodczym. Świadczą one również o rozwoju procesów suburbanizacyjnych. podobnie jak fakt, że na obszarze aglomeracji notowany jest $w$ ostatnich latach wyższy przyrost naturalny niż na obszarze ROM, co jest konsekwencją przenoszenia się na przedmieścia (do obszaru aglomeracji) ludności w wieku rozrodczym.

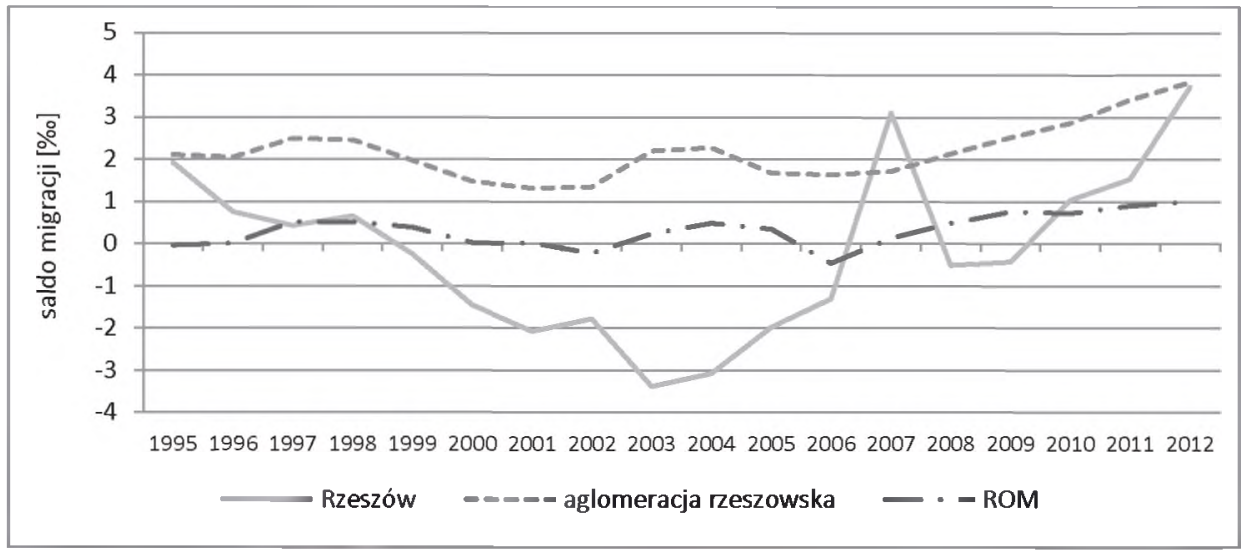

Ryc. 5. Zmiany salda migracji na obszarze Rzeszowa, aglomeracji rzeszowskiej i ROM w latach 1995-2012

Źródło: opracowanie własne na podstawie danych GUS

Analiza salda migracji (ryc. 5) pokazuje, że najwyższymi wartościami tego wskaźnika charakteryzuje się obszar aglomeracji. W badanym okresie wskaźnik ten przyjmuje wartości 
dodatnie (od 1,31 do 3,83\%o) i od 2006 r. charakteryzuje się ciąglym wzrostem. Dla ROM wskaźnik salda migracji jest niższy niż dla obszaru aglomeracji (od -0.47 do 1,0\%o), ale charakteryzuje się ciągłym wzrostem od 2006 r. Ujemne wartości tego wskaźnika występowały w latach 1995, 2002 i 2006. Inaczej natomiast przedstawia się problem salda migracji miasta Rzeszowa. Analiza w tym przypadku jest utrudniona powodu powiększania obszaru miasta. W badanym okresie wskaźnik ten wykazywal tendencję spadkową aż do roku 2003, kiedy osiągnął najniższą wartość -3.39\%o. W latach 1999-2006 wskaźnik salda migracji charakteryzował się ujemnymi wartościami. Sytuacja ta potwierdza rozwój procesów suburbanizacyjnych. Po okresie szybkiego wzrostu w latach 2003-2007 ponownie nastapił spadek salda migracji i ubytek ludności w latach 2008-2009. Od roku 2010 znów notowany jest dodatni wskaźnik salda migracji. Wahania te są spowodowane rozszerzaniem obszaru miasta.

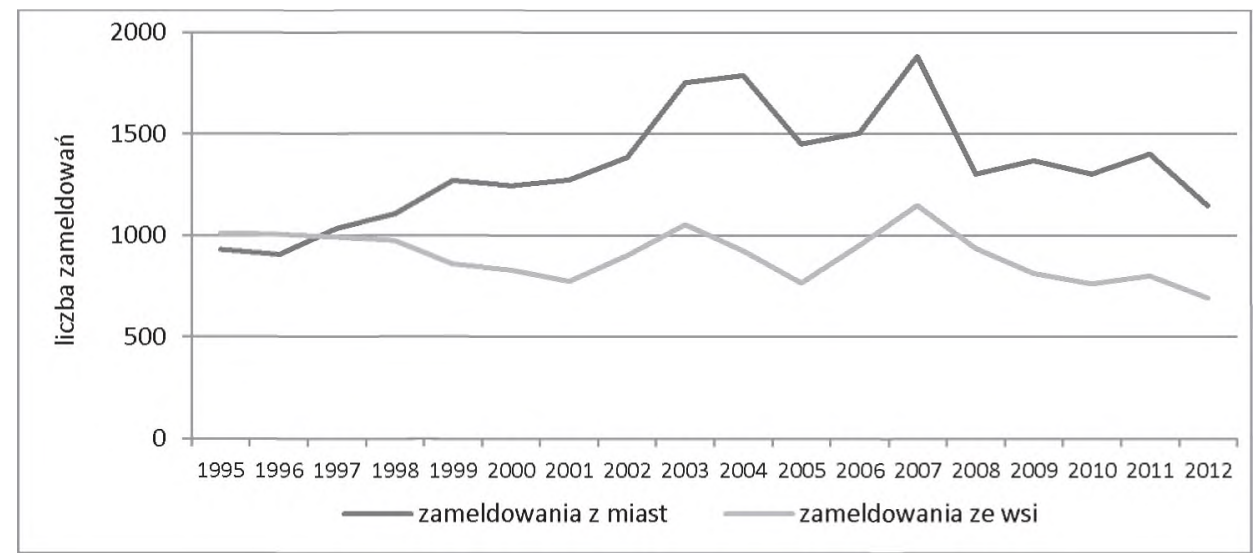

Ryc. 6. Zmiany liczby zameldowań z miast i wsi do obszaru aglomeracji (bez miasta Rzeszowa) w latach 1995-2012

Źródło: opracowanie własne na podstawie danych GUS

Ogólne tendencje wskazują jednak na rozwój procesów suburbanizacyjnych poprzez ciągły napływ ludności do aglomeracji. Potwierdza to także analiza danych dotyczących liczby zameldowań z miast i wsi do obszaru aglomeracji (bez miasta Rzeszowa). Po 1997 r. wyraźnie przeważają bowiem zameldowania z miast nad zameldowaniami z obszarów wiejskich (ryc. 6).

Dane dotyczące poziomu stopy bezrobocia w powiatach ROM z lat 2004-2012 pokazuja, że we wszystkich powiatach stopa bezrobocia osiągnęla najniższy poziom w 2008 r., a następnie wykazywala tendencję wzrostową, która trwa do chwili obecnej (ryc. 7). Wzrost stopy bezrobocia po $2008 \mathrm{r}$. jest to niewątpliwie następstwo ogólnoświatowego kryzysu gospodarczego. Należy również zauważyć, że najniższy poziom bezrobocia w badanym okresie charakteryzuje miasto Rzeszów (stopa bezrobocia waha się od 5,9 do 9,4\%). a w dalszej kolejności powiat dębicki (stopa bezrobocia waha się od 10,2 do 19,0\%) oraz rzeszowski (stopa bezrobocia waha się od 11.3 do $19.0 \%$ ), zaś najwyższy - powiat kolbuszowski (stopa bezrobocia waha się od 14,6 do $22,4 \%$ ) i ropczycko-sędziszowski (stopa bezrobocia waha się od 14.6 do $22.3 \%$ ). 


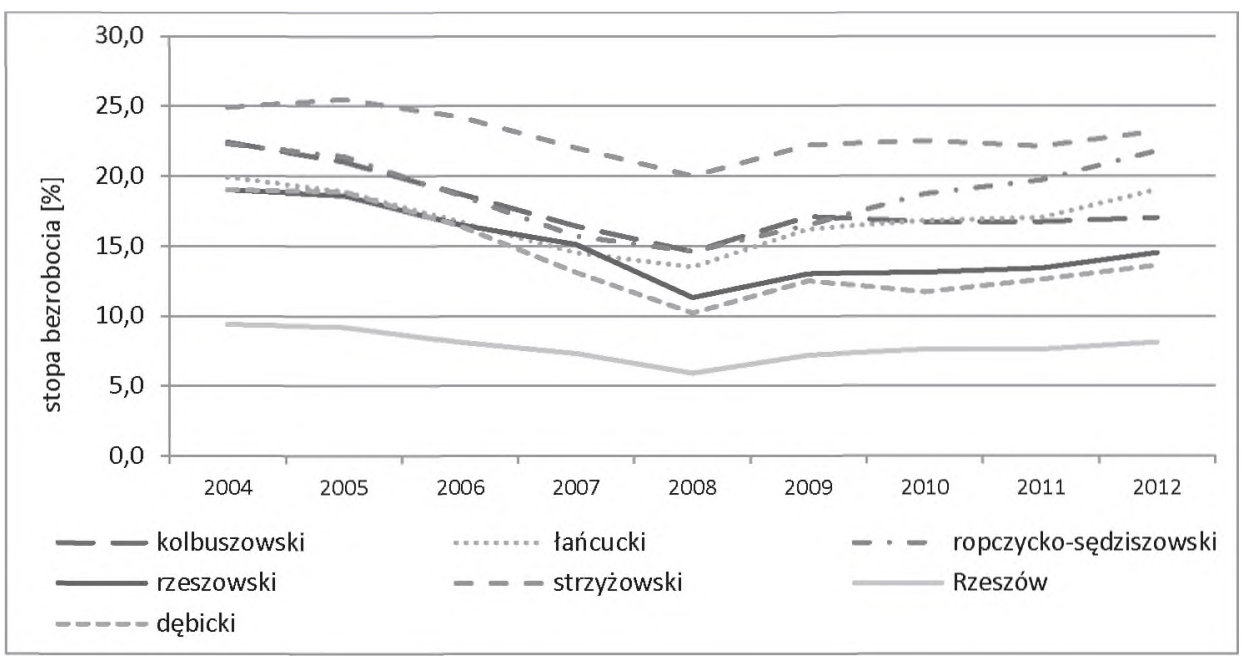

Ryc. 7. Zmiany poziomu stopy bezrobocia w powiatach ROM w latach 2004-2012

Źródło: opracowanie własne na podstawie danych GUS

Kryzys przejawia się również w wysokości nakładów inwestycyjnych w przedsiębiorstwach (tab. 2). Dane za lata 2008-2011 pokazują. że w 4 na 6 powiatów ROM nakłady inwestycyjne na 1 mieszkańca zmalaly, ich wzrost zauważalny jest jedynie w Rzeszowie (wzrost o $18 \%$ ). powiecie rzeszowskim (wzrost o 198\%) oraz powiecie strzyżowskim (wzrost o $119 \%$ ), jednak w tym ostatnim przypadku wzrost byl niewielki, bo zaledwie o ok. 260 tys. zl, co w porównaniu do nakładów w innych powiatach jest kwotą niską. Największy spadek nakładów inwestycyjnych na jednego mieszkańca jest zauważalny w powiecie kolbuszowskim (spadek o 48\%) oraz ropczycko-sędziszowskim (spadek o 46\%). W skali calego ROM nastąpił niewielki wzrost nakladów inwestycyjnych (o 4\%).

Tab. 2. Zmiany nakladów inwestycyjnych w przedsiębiorstwach na jednego mieszkańca w powiatach ROM w latach 2008-2011

\begin{tabular}{|c|c|c|c|c|c|}
\hline \multirow[b]{2}{*}{ Powiat } & \multicolumn{5}{|c|}{ Nakłady inwestycyjne w przedsiębiorstwach na 1 mieszkańca } \\
\hline & 2008 & 2009 & 2010 & 2011 & $\begin{array}{c}\text { dynamika } \\
{[2008=100 \%]}\end{array}$ \\
\hline kolbuszowski & $1957,00 \mathrm{zl}$ & $1024,00 \mathrm{zl}$ & $1039,20 \mathrm{zl}$ & $1011,00 \mathrm{zl}$ & $52 \%$ \\
\hline lańcucki & $1467,00 \mathrm{zl}$ & $929,00 \mathrm{zl}$ & $1040,30 \mathrm{zl}$ & $1361,00 \mathrm{zl}$ & $93 \%$ \\
\hline ropczycko-sędziszowski & $2538,00 \mathrm{zl}$ & $1707,00 \mathrm{zl}$ & $1577,00 \mathrm{zl}$ & $1377,00 \mathrm{zl}$ & $54 \%$ \\
\hline rzeszowski & $1129,00 \mathrm{zl}$ & $1242,00 \mathrm{zl}$ & $2036,80 \mathrm{zl}$ & $3366,00 \mathrm{zl}$ & $298 \%$ \\
\hline strzyżowski & $222,00 \mathrm{zl}$ & $193,00 \mathrm{zl}$ & $331,10 \mathrm{zl}$ & $487,00 \mathrm{zl}$ & $219 \%$ \\
\hline m. Rzeszów & $5505,00 \mathrm{zl}$ & $5478,00 \mathrm{zl}$ & $5076,80 \mathrm{zl}$ & $6522,00 \mathrm{zl}$ & $118 \%$ \\
\hline dębicki & $3010,00 \mathrm{zl}$ & $1853,00 \mathrm{zl}$ & $1977,70 \mathrm{zl}$ & $2264,00 \mathrm{zl}$ & $75 \%$ \\
\hline ROM & $15828,00 \mathrm{zl}$ & $12426,00 \mathrm{zl}$ & $13078,90 \mathrm{zl}$ & $16388,00 \mathrm{zl}$ & $104 \%$ \\
\hline
\end{tabular}

Źródło: opracowanie własne na podstawie danych GUS 
Dane dotyczące liczby mieszkań oddanych do użytkowania w latach 1995-2012 wykazują ogólną tendencję wzrostową (ryc. 8). Największy wzrost liczby oddanych do użytkowania mieszkan jest zauważalny w latach 2002-2003 r. Ma to związek z podwyższeniem podatku VAT na materiały budowlane od 2004 r. - stąd przyspieszone działania deweloperów zmierzające do zakończenia budowy i oddania jak największej liczby inwestycji.

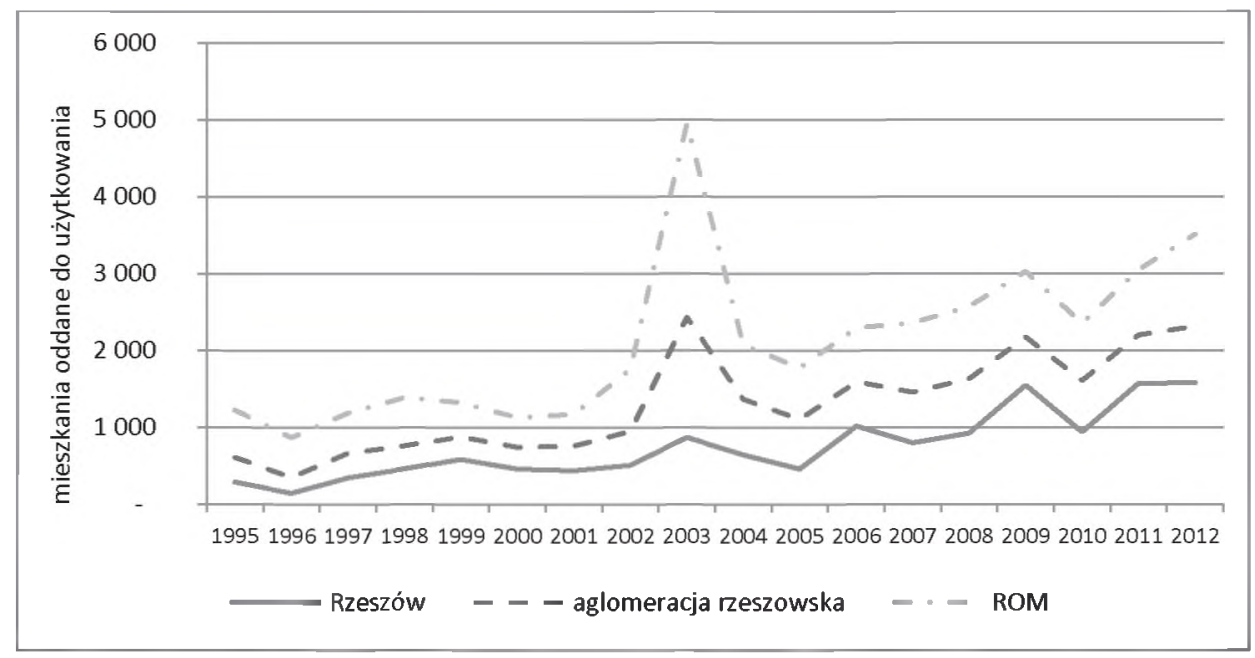

Ryc. 8. Zmiany liczby mieszkań oddanych do użytkowania w Rzeszowie, aglomeracji rzeszowskiej i ROM w latach 1995-2012

Źródło: opracowanie własne na podstawie danych GUS

Po okresie wzrostu liczby oddawanych mieszkań w latach 2005-2009, nastąpil w roku 2010 znaczący spadek, co może być konsekwencją kryzysu, który nie ominął także branży budowlanej. Efektem kryzysu jest bowiem spowolnienie rozwoju budownictwa - szczególnie mieszkaniowego. W obliczu kryzysu konsumenci opóźniają bowiem decyzję o zakupie mieszkań z powodu niepewności na rynku i drogich kredytów. Deweloperzy natomiast. obserwując zachowania potencjalnych nabywców. ostrożniej podejmują decyzje o rozpoczynaniu nowych inwestycji, czego efektem jest wlaśnie spadek liczby mieszkań oddanych do użytkowania.

Spowolnienie rozwoju budownictwa jest widoczne również podczas analizy danych dotyczących pozwoleń wydanych na budowę budynków mieszkalnych (ryc. 9).

Zauważalny jest intensywny wzrost liczby pozwoleń na budowę wydanych w latach 2004-2009. a następnie spadek wydawanych pozwoleń po 2009 r. Jest to konsekwencja kryzysu. który doprowadził do tego, że zarówno deweloperzy, jak i indywidualni inwestorzy obawiają się podejmowania decyzji o inwestycji i zaciągania kredytów w niepewnej sytuacji na rynku i w obliczu kryzysu gospodarczego. Należy podkreślić jednocześnie, że największa liczba pozwoleń na budowę spośród wszystkich powiatów ROM charakteryzuje powiat rzeszowski. Jest to potwierdzenie rozwoju procesów suburbanizacyjnych. 


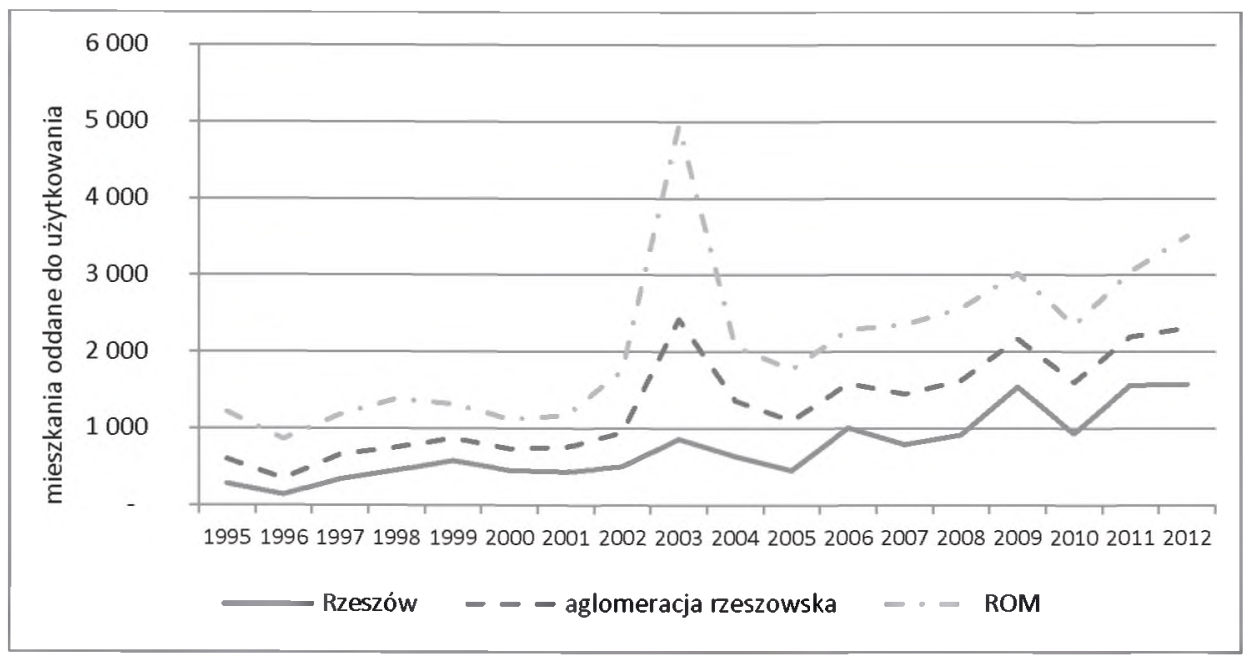

Rvc. 9. Zmiany liczby wydanych pozwoleń na budowę budvnków mieszkalnych w powiatach ROM w latach 2000-2012

Źródło: opracowanie własne na podstawie danych GUS

\section{PODSUMOWANIE}

W świetle przeprowadzonych badań należy stwierdzić, że następuje rozwój procesów suburbanizacyjnych aglomeracji rzeszowskiej. Potwierdzeniem tego są dane dotyczace zmian liczby ludności badanego obszaru - ciągly wzrost liczby mieszkańców obszaru aglomeracji przy jednoczesnym odpływie ludności z miasta centralnego. Także wartości przyrostu naturalnego oraz salda migracji są potwierdzeniem rozwoju suburbanizacji, podobnie jak dane dotyczące liczby zameldowań z miast i wsi do obszaru aglomeracji.

O negatywnym wpływie kryzysu świadczy wzrost stopy bezrobocia po 2008 r. Kryzys przejawia się również $w$ wysokości nakładów inwestycyjnych w przedsiębiorstwach. Także zmiany w liczbie oddawanych mieszkań są konsekwencją kryzysu, który nie ominął branży budowlanej. Jego efektem jest bowiem spowolnienie rozwoju budownictwa, widoczne również podczas analizy danych dotyczących wydanych pozwoleń na budowę budynków mieszkalnych.

Jednak na podstawie przeprowadzonej analizy można mówić jedynie o krótkotrwałym spowolnieniu gospodarczym. Przedstawione dane pozwalają bowiem stwierdzić, że dotychczasowe negatywne skutki kryzysu gospodarczego nie byly tak glębokie. jak można by się było spodziewać, a na podstawie dokonanej analizy należy przypuszczać, że w następnych latach będzie następowal dalszy rozwój procesów suburbanizacyjnych badanego obszaru. 


\section{Literatura}

References

Adamczyk, M. (2012). Współczesny kryzys finansowy - przyczyny i konsekwencje dla gospodarki światowej. Wyzwania gospodarki globalnej. Prace i materialy Instytutu Handlu Zagranicznego Uniwersytetu Gdańskiego, 31(1), 13-29.

Gorzelak, G., Smętkowski, M., Jalowiecki, B. (2009). Obszary metropolitalne w Polsce - diagnoza i rekomendacje. Studia Regionalne i Lokalne, 1(35), 52-73.

Jałowiecki, B. (1999). Współczesne przekształcenia struktury osadniczej i przestrzeni miejskiej. W: J. Kolodziejski, T. Parteka (red.). Cywilizacja informacyjna a przeksztalcenia przestrzeni. Zmiany strukturalne metropolii polskich. Biuletyn Komitetu Przestrzennego Zagospodarowania Kraju Polskiej Akademii Nauk, 186, 27-76.

Kudełko, J. (red.). (2007). Uwarunkowania rozwoju Rzeszowskiego Obszaru Metropolitalnego w systemie spoleczno-gospodarczym i innowacyjnym województwa podkarpackiego. Prace Komisji Nauk Ekonomicznych Sekcja Gospodarki Przestrzennej Komisji Nauk Ekonomicznych, 25.

l.1sowski, A., Grochowskı, M. (2009). Procesy suburbanizacji. Uwarunkowania, formy i konsekwencje. W: Ekspertyzy do Koncepcji Zagospodarowania Przestrzennego Kraju. Warszawa: Ministerstwo Rozwoju Regionalnego, 217-281

Makiela, Z., Fedan, R. (red.). (2007). Procesy metropolizacji w regionie podkarpackim Rzeszów-Lwów. Buletyn Komitetu Przestrzennego Zagospodarowania Kraju Polskiej Akademii Nauk, 230

Markowski, T., Marszal, T. (2006). Metropolie. Obszary Metropolitalne. Metropolizacja. Problemy i pojęcia podstowowe. Warszawa: Komitet Przestrzennego Zagospodarowania Kraju Polskiej Akademii Nauk.

Plan Zagospodarowania Przestrzennego Województwa Podkarpackiego (2002). Rzeszów: Zarząd Województwa Podkarpackiego.

Rachwal, T. (2011). Wplyw kryzysu na zmiany produkcji przemysłowej w Polsce. Prace Komisji Geografii Przemystu Polskiego Towarzystwa Geograficznego, 17, 99-113.

Słodczyk, J. (red.). (2011). Studia Miejskie 3: Procesy suburbanizacji w wybranych miastach Polski. Opole: Wydawnictwo Uniwersytetu Opolskiego.

Śleszyński, P., Czapiewski, Ł. (2011). Znaczenie ośrodków miejskich oraz ich hierarchicznych powiazań dla regionalnego i lokalnego rozwoju ekonomicznego i spolecznego polski wschodniej. Ekspertyza wykonana na zlecenie Ministerstwa Rozwoju Regionalnego na potrzeby aktualizacji Strategii rozwoju społeczno-gospodarczego Polski Wschodniej do roku 2020. Warszawa: Instytut Geografii i Przestrzennego Zagospodarowania Polskiej Akademii Nauk.

Śleszyński, P. (2006). Demograficzny wymiar procesów suburbanizacji w Polsce po 1989 roku. W: S. Kozłowski (red.). Żywiołowe rozprzestrzenianie się miast. Narastający problem aglomeracji miejskich w Polsce. Studia nad zrównoważonym rozwojem, t. 2, Białystok-Lublin-Warszawa: Katedra Ochrony Środowiska KUL, Komitet „Czlowiek i Środowisko" przy Prezydium PAN, $105-123$.

Sleszyński, P. (2007). Gospodarcze funkcje kontrolne w przestrzeni Polski. Warszawa: Instytut Geografii i Przestrzennego Zagospodarowania Polskiej Akademii Nauk.

Śleszyński, P. (2012). Kierunki dojazdów do pracy. Wiadomości statystyczne, 11, 59-75.

Śleszyński, P. (2013). Delimitacja Miejskich Obszarów Funkcjonalnych stolic województw. Przegląd Geograficzny, 2(85), 173-197.

Winiarczyk-Raźniak, A., Raźniak, P. (2012). Migracje wewnętrzne ludności w polskich obszarach metropolitalnych u progu XXI wieku. Kraków: Wydawnictwo Naukowe Uniwersytetu Pedagogicznego.

Zioło, Z. (2011). Wplyw światowego kryzysu na tempo wzrostu gospodarki i światowych korporacji. Prace Komisji Geografii Przemvslu Polskiego Towarzystwa Geograficznego, 17, 9-32. 
Źródla internetowe:

http://www.stat.gov.pl/bdl

http://www.rzeszow.pl/miasto-rzeszow/rozszerzenie-granic-miasta/jak-roslo-nasze-miasto

Agnieszka Luków, mgr inż., doktorantka w Instytucie Geografii Uniwersytetu Pedagogicznego im. KEN w Krakowie. Absolwentka Wydziału Geograficzno-Biologicznego Uniwersytetu Pedagogicznego w Krakowie na kierunkach: geografia (2010 r.) oraz ochrona środowiska (2012 r.). Obecnie uczestniczka studiów doktoranckich w zakresie geografii oraz pracownik Wojewódzkiej Inspekcji Geodezyjnej i Kartograficznej Malopolskiego Urzędu Wojewódzkiego w Krakowie. Zainteresowania badawcze: przebieg procesów suburbanizacyjnych w aglomeracji rzeszowskiej, rozwój Rzeszowskiego Obszaru Metropolitalnego.

Agnieszka Luków, Ph.D. student at the Institute of Geography of the Pedagogical University in Krakow. Graduated from the Faculty of Geography and Biology Pedagogical University of Cracow disciplines: geography (2010) and the environment (2012). Currently a Ph.D. student of geography, an employee of the Provincial Inspectorate of Geodesy and Cartography of the Malopolska Provincial Office in Krakow. Research interests: suburbanization in the agglomeration of Rzeszow, development of the Rzeszow Metropolitan Area.

\section{Adres/adress:}

Uniwersytet Pedagogiczny w Krakowie

Instytut Geografii

ul. Podchorążych 2, 30-084 Kraków, Polska

e-mail: aga.lukow@gmail.com 